\title{
'Renewal is the Universal Call': Trials of Reason in Edmund Husserl
}

\author{
Nathan Phillips
}

And then there is the symbol of Rembrandt, which truly does not just hang on my wall like a dead picture: Jacob's battle with God, 'til his ribs crack - and his God as the angel blesses him.

Letter of Edmund Husserl to Eugen Fink, March 6, 1933 (Briefwechsel 4, 91)1

The two themes of "crisis" and "renewal" cut across the writings of Edmund Husserl (1859-1938), the founder of twentieth-century phenomenology. On the one hand, Husserl consistently highlights what he regards as a prevailing "crisis" of philosophical rationality, from the critique of psychologism in the Prolegomena to the Logische Untersuchungen (1900-1901)2 to the final meditations on the life-world in Die Krisis der europäischen Wissenschaften und die transzendentale Phänomenologie in the late1930s. ${ }^{3}$ Yet the discussion of "crisis" is everywhere intertwined with a discusssion of "renewal." The four short articles commissioned by the Japanese periodical Kaizo in 1922-1924,4 bring to a fullness of presentation the ethical and social issues related to the problem of "renewal" in the time of cultural "crisis." When we find Husserl again returning to the topic in the mid-1930s, this time in a lecture to the Vienna Kulturband in May of 1935, the mobilization of the events to come were already upon Husserl's mind and in the general horizon. This paper will examine themes of "crisis" and "renewal" in three central texts: Husserl's manifesto, "Philosophie als strenge Wissenschaft,"5 published in the journal Logos in 1910-1911; the Kaizo articles on "renewal" from 1922-1924, and the 1935 Vienna lecture on "Die Krisis des euopäischen Men-

${ }^{1}$ Edmund Husserl, Briefwechsel. Band IV. Dordrecht: Kluwer Academic Publishers, 1994, p. 91. Cited by Marcus Brainard, Belief and its Neutralization, New York: State University of New York Press, 2002, p. 249n70.

2 Edmund Husserl, Logische Untersuchungen. Erster Band: Prolegomena zur reinen Logik. Husserliana XVIII. The Hague: Martinus Nijhoff Publishers, 1975. English translation: Logical Investigations, trans. J. N. Findlay, New York: Routledge Publishing, 2001.

${ }^{3}$ Edmund Husserl, Die Krisis der europäischen Wissenschaften und die transzendentale Phänomenologie. Husserliana VI. The Hague: Martinus Nijhoff Publishers, 1954. English translation: The Crisis of European Sciences and Transcendental Phenomenology, trans. David Carr, Evanston: Northwestern University Press, 1970.

${ }^{4}$ Edmund Husserl, "Fünf Aufsätze über Erneuerung," in Aufsätze und Vorträge, Husserliana XXVI. Dordrecht: Kluwer Academic Publishers, 1989. The first article "Renewal: Its Problem and Method," is translated in Husserl: Shorter Works, trans. Jeffner Allen, University of Notre Dame Press, 1981, pp. 326-331.

5 Edmund Husserl, "Philosophie als strenge Wissenschaft," in Aufsätze und Vorträge, Husserliana XXV. Dordrecht: Martinus Nijhoff Publishers, 1987. English translation: "Philosophy as Rigorous Science," trans. Marcus Brainard, in The New Yearbook for Phenomenology and Phenomenological Philosophy II (2002), pp. 249-295. 
schentums und die Philosophie."6 In so doing, this paper will provide a sketch for the phenomenology of "natural law" and "human rights."

For Edmund Husserl, "Europe" is first and foremost an idea. ${ }^{7}$ The meaning of "Europe" is thus not limited to the geographical location of the European contintent, but extends to wherever the idea of "Europe" is found. For Husserl, the essence of "European" civilization and culture is found in a constant return to the original source of inspiration for philosophical reflection found with the ancient Greeks. It is only with philosophy, Husserl writes, that the critical question of how one comes to know something for sure, the question of evidence, is first addressed. And it is with Plato that the original philosophical drive is brought into the systematic form of philosophy, the demand that all true knowledge be contained within a universe of pure ideas. ${ }^{8}$ The idea of "Europe" is thus connected for Husserl with a certain understanding of the philosophical drive as a "will to truth," according to a certain type of "rational activity." The "will to truth" is concerned not with finite goods attained in a practical way, but with truth itself, that is, absolute and unconditioned truth. To be concerned with absolute and unconditioned truth is to be open to the possibility for an infinite extension of the "will to truth." For to speak about absolute truth is to be positioned toward that which cannot be circumscribed. To open the sense of truth beyond the partial horizons of a finite humanity is the beginning of the development of the idea of "Europe," willingness for infinite tasks.

The modern world is a world which no longer believes in its capacity for absolute truth. After the Hegelian synthesis, and with the rise of the natural sciences, Husserl identifies a growing sense of skepticism, an incapacity or unwillingness to believe in a pure ideality or in the univocal direction of history toward an absolute end. Thus the prevailing sense of history is taken from Hegel but turned into a relativistic historicism. The "crisis" that results from the development of nineteenth century thought was the "making finite" of the human imagination. Husserl sees in the political fallout from the First World War a "pessimism," a "self-interestedness," and an "utterly degenerate nationalism." 9 The Realpolitiker no longer speak about "possibilities," but only about "realities" and "actualities." The general reason for the pessimism and self-interestedness at the personal and social levels stems from a skepticism regarding the end and

${ }^{6}$ Edmund Husserl, "Die Krisis des euopäischen Menschentums und die Philosophie," in Husserliana VI, pp. 314-348. English translation: "Philosophy and the Crisis of European Humanity," in The Crisis of European Sciences and Transcendental Phenomenology, pp. 269-299. This text, along with "Philosophy as Rigorous Science," are found in Phenomenology and the Crisis of Philosophy, trans. Quentin Lauer, New York: Harper \& Row, 1965.

${ }^{7}$ Hua. VI, p. 319f., English trans., p. $274 f$.

${ }^{8}$ Edmund Husserl, "Die Idee einer philosophischen Kultur. Ihr erstes Aufkeimen in der griechischen Philosophie," in Japanisch-Deutsche Zeitschrift für Wissenschaft und Technik 1 (1923), pp. 45-51. See also Edmund Husserl, Erste Philosophie (1923/24). Erster Teil. Kritische Ideengeschichte, ed. Rudolf Boehm, Husserliana VII. The Hague: Marintus Nijhoff Publishers, 1956). English translation: "The Idea of a Philosophical Culture: Its First Germination in Greek Philosophy," trans. Marcus Brainard, in The New Yearbook for Phenomenology and Phenomenological Philosophy III (2003), pp. 285-293.

${ }^{9}$ Hua. XXVI, pp. 5-6 English trans., p. 326. 
purpose of human activity, and by extension, the meaning of the common good. The principles which direct community life remain unclarified and ambiguous.

The challenge is to locate a principle which can both resist devalution [Entwertung] and can stand at the center for cultural renewal.10 This is a universal project for Husserl, and requires change at the most fundamental levels of human inquiry. Since the need itself stems from the sciences, it is to the sciences, defined as systems for the production of knowledge, that Husserl turns his attention. What is needed is "the 'positive,' hence principial, critique of foundations, methods, accomplishments [...] Our age is according to its vocation a great age - only it suffers from the neglible development and force of philosophy, which has not yet progressed enough to overcome skeptical negativism (which calls itself positivism) by means a true positivism."11 The first task of science is to make valid, rational, distinctions concerning the order of knowledge. Revolutions in the history of science occur through the critique of presumed foundations and methods of previous sciences. Husserl sees the immediate task of phenomenology as a preparatory science, in the sense of laying the groundwork for the development of the sciences into their fullest and highest possibilities. "There cannot be any doubt about what our duty is. It is a matter of personally searching for the scientific ways which, unfortunately, no previous science has prepared."12 In order to maintain an absolutely secured position against devaluation [Entwertung], the new science must be an eidetic science, a science of essences: "The only fruitful type of reflection is the one that is essential reflection [Wesensbetrachtung], for only it can open the way to rational science that not only treats human being as such, but also the renewal of human being." 13 To the extent that phenomenology as an eidetic science is intended to provoke a renewal in all orders of rational life, the field of research for phenomenology must be rooted in the essence of the human being. Since the human being is only possible within human communities, phenomenology aims to be a "rational science of the human being and the human community." 14

Thus, the problem for Husserl is the "crisis" of philosophical rationality, the meth$o d$ is the research of essences, and the field of research is the human being and the human community. The final end of phenomenology would be "a universal philosophy that has given itself in its principial disciplines its absolute system of laws, the universal law for all possible, genuine laws."15 The universal law of phenomenology concerns "the truly humane development of humanity" [eine wahrhaft humane Menschheit-

10 See Friedrich Nietzsche, Der Wille zur Macht, Kröner, 1996, p. 10: "Was bedeutet Nihilismus? Daß die obersten Werte sich entwerten. Es fehlt das Ziel; es fehlt die Antwort auf das 'Warum'?” See also Martin Heidegger, "Nietzsches Wort 'Gott ist tot,"” in Holzwege, Klostermann, 2003, pp. 222-223. English trans., "Nietzsche's Word, 'God is Dead," in Off the Beaten Path, trans. Julian Young and Kenneth Haynes, p. 166f.

${ }^{11}$ Hua. XXV, pp. 297, 340, English trans., pp. 256, 293.

12 Hua., XXVI, p. 14, English trans., p. 331.

13 Hua., XXVI, p. 14, English trans., p. 331.

${ }^{14}$ Hua., XXVI, p. 6, English trans., p. 328.

15 Hua., VII, p. 46, English trans.,p. 287, 
sentwicklung]. ${ }^{16}$ Universal law in the sense of "a development toward an ideal shape of life and being as an eternal pole" [einer Entwicklung auf eine ideale Lebens- und Seinsgestalt als einen ewigen Pol. $]^{17}$

In developing this science of "purely rational, a priori truths rooted in the essence of human being," Husserl draws the comparison between the eidetic method for determining the pure idea of human beings [Idee des Menschen] and human community, and the method for determining the idea of nature [Idee der Natur] in mathematical-natural sciences. ${ }^{18}$ The mathematical-natural sciences enable the scientist to perceive in the things of nature not merely pre-existing actualities or realites, but the order of possibilities or essences. The greatness of the natural sciences, for Husserl, is that they do not rest content with merely empirical observation, but strive to find within the empiricalintuitive the passage to exact explanation. The natural scientist identifies within the intuitively given appearances of nature not merely subjective-relative aspects of human perception, but the "objective" features of "nature itself." That is, according to the method of the natural sciences, the relativities of sensible experience are sublimated into an overarching structure of pure ideas. To see nature in this way is to construct a system of "true" nature determined by "natural" laws, "encompassed by homogeneous space-time, divided into particular things, all being alike as res extensa and determining one another causally."19 Pre-determined nature, within the causal nexus of the homogeneous space-time, is thus divisible to infinity and extendable to infinity by way of "the idealization of magnitudes, of numbers, figures, straight-lines, poles, surfaces, etc." 20 In fact, there is no perfect "circle" in nature, but the mathematician abstracts from the relativities of experience to derive the idea of the "circle itself." This method of idealization first becomes necessary due to the exigencies of practical life: "From the art of surveying comes geometry, from the art of numbers, arithmetic, from everyday mechanics, mathematical mechanics, etc."21 Intuitively given natural world is made into the "true" mathematical world, thus open to increasing perfection and refinement due to an infinite adequation to pure ideas.

If we perform a similar eidetic analysis on the pure idea of human beings [Idee des Menschen], the goal would be to develop a measure for evaluating and directing the course of the development of human beings in general [überhaupt], in terms of individual human beings and the universal human community. The most immediate demand concerns the standard by which an evaluation of human beings and human community might be secured. If Husserl's critical philosophical gaze renders a judgment of condemnation on the existing state of things, there must be some barometer or point of reference for the justification of such a judgment: "Implicit in our judgment is our

16 Hua., VII, p. 46, English trans., p. 287.

${ }^{17}$ Hua., VI, p. 320, English trans., p. 276.

18 Hua., XXVI, p. 6, English trans., p. 328.

19 Hua., VI, p. 340, English trans., p. 293.

${ }^{20}$ Hua., VI, p. 340, English trans., p. 293.

${ }^{21}$ Hua., VI, p. 340, English trans. p. 293 
belief in a 'true and genuine' humanity as an objectively valid idea," 22 [...] "An idea against which, therefore, the social bonds of humanity and historically developed forms of social life are to be judged normatively." 23 Thus the goal of reform in human community must aim at the fulfillment or realization of pure ideas.

Husserl describes ideas as "meaning-structures" [Sinngebilde] which have "the miraculous way of containing intentional infinities [intentionale Unendlichkeiten] within themselves." 24 Ideas contain goals for the will in terms of pure possibilities over and above the real things within space-time. When an idea becomes the conscious aim of the will, then the idea is translated back into the real in terms of a newly transformed praxis. This new praxis in relation to the pure ideas implies a universal critical attitude toward the nature of the real. The critical attitude of the philosopher toward the pregiven universe both makes way for the production of new ideas and has the reflexive effect of reforming the state of the existing order. Thus, the ideas make a difference in two directions, both in terms of an infinite extension toward the idea itself, and in terms of the infinite critique of all things not yet in conformity with the idea. The production of pure ideas generates a universe of normative principles which unfold beneath the pure idea and serve to mediate the progress of humanity to the idea itself.

With the production of pure ideas, existing human beings find within the flux of temporal reality the traces of something eternal, the pure idea that compels an infinite extension of ideals aiming in a normative fashion toward the idea itself. But the goal of the pure idea must not be some merely utopian fantasy; rather the idea itself must always be derived as a possibility through imaginative variations of the existing actualities. The recognition of essential truths for Husserl does not pre-exist the givenness of the real. It is by means of the given that an intuition into the absolute is possible. If the end is the transformation of humanity into a new humanity ["zu einem von Grund aus neuen Menschentum zu wandeln]," then the ideas which direct humanity must be derived from a critique of the essence of humanity itself ["Kritik der Menschheit selbst"] ${ }^{25}$ If humanity is always "on the way" to the realization of its essence, even unto infinity, then the norms and principles related to this essence must themselves share in this essential openness. To derive pure norms from an eidetic analysis of the existing conditions of humanity is to recognize that this exercise of thinking is itself historically circumscribed and relative to the particular horizons within which the activity of thinking is located. It must be insisted that any principle for the "truly human development of humanity" [eine wahrhaft humane Menschheitsentwicklung] ${ }^{26}$ must find its condition of possibility within the finitude and openness of human existence. The derivation of pure possibilities from actually existing realities, across time and space, implies the transformation of the actual according to the order of the possible. Thus the possible

22 Hua., XXVI, p. 10, English trans., p. 330.

${ }^{23}$ Hua., VII, pp. 50-51, English trans., p. 292.

24 Hua., VI, p. 320, English trans., pp. 276-277.

25 Hua., VI, p. 329, English trans., p. 283.

26 Hua., VII, p. 46, English trans., p. 287, 
stands higher than the actual, but it is only within the actual that the possible can be realized.

The individual human being is a priori, that is, essentially, connected to human community ["a priori untrennbare Ideenpaar: Einzelmensch und Gemeinschaft]. With the production of ideas, a new sort of communalization becomes possible around the common devotion to pure ideas. The production of ideas implies a different sense of time and historicity, and the repeated production of ideas does not end in lack, but in more ideas, "identical in sense and validity" ["identisch nach Sinn und Geltung"] 27 across cultural and temporal boundaries and barriers. To live with a mind to absolute universality, sub specie aeterni, is to make possible new forms and standards for human sociality and community: "Because of the requirement to subject all empirical matters to ideal norms, i.e., those of unconditioned truth, there soon results a far-reaching transformation of the whole praxis of human existence, i.e., the whole of cultural life. Henceforth it must receive norms not from naïve experience and tradition of everyday life but from objective truth [...] If the general idea of truth-in-itself becomes the universal norm of all the relative truths that arise in human life, the actual and supposed situational truths, then this will affect all traditional norms, those of right, of beauty, of usefulness, dominant personal values, values connected with personal characteristics."28 It is important to highlight that for Husserl the essence of human being is becoming or development. Positive and negative values are differentiated according to a development-form on the scale of an infinite continuum. ${ }^{29}$ Each of these levels are subordinated to the idea which radiates from above and draws them creatively above themselves. This idea is the lure that compels creative becoming internal to the process itself. The idea generates activity from within, and stands apart or transcends any pregiven state as being always more infinite.

A distinction must be made here between the mere "having" of an idea and the realization or the fulfillment of the idea. Husserl identifies the former as faith, or doxa, that which always stands beneath the possibility for knowledge. Knowledge, or episteme, is the fulfillment and overcoming of faith in realization. ${ }^{30}$ The uniqueness of this faith is that it contains in itself its own self-overcoming. To assume this faith is to be dissociated from any pre-given reality for the sake of what is always more. Faith is always essentially related to a certain attitude [Einstellung] or attunement. Faith implies an attitude toward reality that itself includes the normative structures of a developmentform. "All life is taking position [Stellungnehmen], and all taking of position is subject to a "must" - that of doing justice [Rechtsprechung] to validity and invalidity according to alleged norms of absolute validation." 31 The faith-position always implies a certain style of life, a style which frames the possibilities which are given in terms of the ulti-

${ }^{27}$ Hua., VI, p. 323, English trans., p. 278.

${ }^{28}$ Hua., VI, p. 334, English trans., p. 287.

29 See "Die höhere Wertform einer humanen Menschheit," in Hua., XXVI, pp. 55-59.

${ }^{30}$ Hua., VI, p. 332, English trans., p. 285.

${ }^{31}$ Hua. XXV, p. 336, English trans , p. 290 
mate ends of a development-form: "Attitude, generally speaking, means a habitually fixed style of willing life, comprising directions of the will or interests that are prescribed by this style, comprising the ultimate ends, the cultural accomplishments, whose total style is thereby determined." 32 There is no life without some basic faith regarding what is actual and what is possible.

Husserl often attributes the "crisis" to a general "lack of faith," a "making superficial," or a "making finite" of the ultimate ends of faith. Thus the "crisis" of faith, which is simultaneously the "crisis" of style, Husserl relates to a stubbornness or dogmatism concerning the possibilities for knowledge. The "lack of faith" is attributed to a resolute inability or incapacity to separate oneself from the pre-given realities of the surrounding world [Umwelt]. For Husserl, the skepticism regarding faith is finally related to a dogmatism of the world, "the natural, naïve attitude which does not know what it does to the extent that it believes in the world and is ignorant of the reasons for this belief."33

If all life implies some faith-position, then the opening of a development-form to the infinite implies the reorientation [Umstellung] of certain fundamental attitudes. Thus the emergence of the philosophical attitude implies a change or modification of some more basic, primordial attitude, what Husserl identifies as the natural attitude. ${ }^{34}$ This natural attitude implies a certain understanding or faith regarding the human community, the directedness of the will, and the world. If the attitude or style serves to direct and form the intentions, then the natural attitude is oriented in an external way toward the world as pre-given and present in a definite object-oriented way. The natural attitude assumes the pre-given validity of the real in terms of the dominant themes of everyday experience. The intention is straightforwardly directed to objects that it assumes to have a real existence in themselves, apart from and independent of the life within which the objects appear. The natural attitude might also be described as a certain tribalism; each natural life is born into the nuclear community, and the natural attitude does not engage in a critical reflection regarding the meaning of and the responsibility to "humanity itself." The natural attitude only cares for its most immediate needs within the closed community of the same. Finally, the meaning of the world, which Husserl will describe in terms of a most primordial faith [Weltthesis], is restricted to the collection of external objects within a closed horizon. No effort is made to consider the "world as such," to reflect on the horizons that circumscribe existence, to question their validity, to ask the most basic philosophical question, "Why is there something rather than nothing?" Instead one remains circumscribed within a dogmatic universe closed upon itself, operating according to a pre-given cosmology or metaphysics.

32 Hua., VI, p. 326, English trans., p. 280.

33 See Maurice Merleau-Ponty, Nature: Course Notes from the Collège de France, Northwestern University Press, 2003, p. 71 f.

34 On the difference between the "natural" and the "transcendental" attitude, see Dermot Moran, "Husserl's Transcendental Philosophy and the Critique of Naturalism," in Continental Philosophy Review, 41.4., pp. 401-25. 
While the natural attitude stands as the dominant pre-given attitude, in truth the natural order is always already superseded by the personal order. We are not dealing with two orders of equal rights, the natural order and the personal order. ${ }^{35}$ It is the personal order that takes priority and enables the scientist to perform abstractions upon the surrounding world [Umwelt] in order to arrive at objective facts. Thus, the human being is in the curious position of being divided between two orders, the natural order and the personal order. "The human being belongs to the sphere of objective facts, but as persons, as egos, human beings have goals, ends, norms, given by the tradition, norms of truth, eternal norms." 36 If the extension of natural science is possible only on the basis of the surrounding world, more primordial still is the human and cultural lifeworld [Lebenswelt]. "The researcher of nature does not make it clear to himself that the constant fundament of his work of thought is the life-world [Lebensumwelt]. The lifeworld is always presupposed as the ground, as the field of work upon which alone the researcher's questions, the method of thought, make sense." 37 In order for anything to be given in advance, there must be a world within which the given are situated. The natural attitude is informed and constituted relative to a pre-given historical epoch and to the normality of the personal home-world [Heimwelt], as opposed to the other worlds deemed foreign [Fremdwelt]. ${ }^{38}$ Thus, a personal or social habitus structures the perception of things according to a pre-given normative frame, which demarcates in advance the differences between normal and abnormal.

The "worldview" [Weltanschauung] for a human community is always already pregiven, handed down by tradition and custom. "Wisdom" [Weisheit] for worldview philosophy implies "living up to" the system of highest values: "The value of worldview philosophy (and thereby also the value of striving for such a philosophy) is primarily conditioned by the value of wisdom and striving for wisdom." 39 In this sense, the end or goal of worldview philosophy is a highly refined technique of living in accordance with a pre-given set of values, "by way of a constant approach, like morality."40 Thus, the worldview of any pre-given cultural horizon provides a dominant paradigm or habit of interpretation that frames the way in which things appear as such. For instance, the meaning of nature for the ancient Greeks, complete with the pantheon of gods, is far removed from the cultural frames of the contemporary European world. ${ }^{41}$ Husserl interprets this fact in critical terms. If the natural scientist understands what ultimately "is" in terms of "nature," and the humanist in terms of "spirit," "both are

35 Hua., VI, p. 316, English trans., p. 271.

36 Hua., VI, p. 341, English trans., p. 293.

${ }^{37}$ Hua., VI, p. 342, English trans., p. 295.

38 See Anthony Steinbock, Home and Beyond: Generative Phenomenology after Husserl, Northwestern University Press, 1995.

39 Hua. XXV, p. 331, English trans., p. 285.

40 Hua. XXV, p. 333, English trans., p. 287.

${ }^{41}$ Hua., VI, p. 317, English trans., p. 272 
inclined to falsify the sense of what cannot be seen in their way."42 And yet the world is always already there as the necessary pre-given for any other experience, scientific or otherwise. "Is it not absurd [widersinnig] and circular [ein Zirkel] to want to explain the historical event "natural science" in a natural-scientific way, to explain it by bringing in natural science and its natural laws [Naturgesetze], which, as spiritual accomplishment, themselves belong to the problem?" 43 Here Husserl introduces the problem of the vicious circle, the problem of self-referentiality for pre-given systems of knowledge.

The historical overturning of systems of value, the fact of paradigm-shifts in the sciences, the revolutions in the fundamental principles and orientations in human cultures and civilizations, all point to a general relativity, and thus to a danger for philosophy that is concerned with radically non-relative, absolute truth, always "on the way" unto infinity. Herein lies the principal vocation of the philosopher: to maintain a universally critical attitude, to pursue the essence, to search for truth in general, to understand particular contingencies of life in light of what is essential. The universality of the philosophical attitude is tied to a radical critique of the pre-given: "If, however, in specifying the sense of our age we apply ourselves to this great goal, we must also make clear to ourselves that we can achieve it in only one way, which is to say, if with the radicalism belonging to the essence of genuine philosophical science we accept nothing given in advance, allow nothing traditional to pass as a beginning, nor ourselves to be dazzled by any names however great, but rather seek to attain the beginnings in a free dedication to problems themselves and to the demands stemming from them." 44

The vocation of the philosopher is to be devoted to pure ideas, thus to the true and full sense of any given thing. No one particular perspective on the things, nor one single truth or insight about things, may be isolated in abstraction from the universal coming to fullness of the things themselves. An example may be drawn here from Husserl's analysis of adumbration [Abschattung] in $\S 41$ of Ideas 1.45 In a perception of the thing, one is limited to a particular perspective, thus to one particular side of the thing seen. In experimental consciousness, a series of observations will result in a multifaceted system of perspectives which together will make up the fullness of intuition. Implied in any perspective is the back-side which remains concealed internal to any given particular standpoint. Thus any perspective contains within itself by an essential necessity the transcending apperception which indicates the possibility for the disclosure of further sides. Thus no single perspective can be isolated from the interrelated system of per-

42 Hua. XXV, p. 294, English trans., p. 253.

43 Hua. VI, p. 318, English trans., p. 273.

44 Hua. XXV, p. 340, English trans., p. 293.

45 Edmund Husserl, Ideen zu einer reinen Phänomenologie und phänomenologischen Philosophie. Erstes Buch: Allgemeine Einführung in die reine Phänomenologie. Husserliana III. The Hague: Martinus Nijhoff Publishers, 1950, pp. 91-95. English translation: Ideas Pertaining to a Pure Phenomenology and to a Phenomenological Philosophy. First Book: General Introduction to a Pure Phenomenology, trans. F. Kersten, The Hague: Martinus Nijhoff Publishers, 1983, pp 86-89. 
spectives, or from the possibility of analogical extension or transcendence. Likewise, any worldview implies a pre-given ideal of perfection or wisdom, and any realization of this ideal assumes repetitions of aspects of it, with the concomitant possibility for evergreater realizations. The ideal of perfect ability achievable in accord with the measure proper to a respective achievement is a "relatively perfect adumbration [Abschattung] of the idea of humanity." 46

Yet the philosopher is not concerned with any particular point of view [Gesichtspunkt] but wants to know what the thing is, in itself and according to its own proper integrity. The essence is absolute and allows for no partiality. "There is the constant threat of succumbing to one-sidedness and to premature satisfaction, which take their revenge [rächen] in subsequent contradictions." 47 Thus, the worldview philosophy can end in a resentment against the universality of truth. This resentment is not merely a matter of celebrating one point of view to the exclusion of others, or even of assuming the totality of truth when such a totality has not yet been achieved. The "revenge" emerges out of a disposition or an aspiration internal to the "will to truth" itself, a certain "crisis" of mentality that assumes to evaluate truth according to its own measure. The aspiration of philosophy, however, is reorientation of attitude [Umstellung] that turns away from straightforward and objective perspectives, to assume a different sort of position or faith. This "conversion" implies the constant struggle to overcome all one-sided perspective and premature satisfaction for the sake of the truth. ${ }^{48}$

To be sure, this self-overcoming includes the critical attitude tied to rigorous universality, the production of ideas due to an imaginative variation and eidetic insight, multiplication of viewpoints in the approach to the thing, and the strength of character implied in the pursuit of wisdom within a human community. But the ultimate, and indeed decisive, turn, is the radical receptivity to the givenness of the thing itself. To assumes this position, faith of the theoretical philosopher, is to suspend one's commitments to a pre-given world. It is thus not practical in any usual sense, but it remains detached in a critical attitude open to the sense of wonder: "Incipient theoretical curiosity as wonder [thaumazein] has its original place in normal life as an intrusion into the course of serious living, either as a result of originally developed life-interests or as playful looking around when one's quite immediate vital needs are satisfied or when working hours are over. Curiosity (here understood not as a habitual "vice") is also a variant, an interest, which has separated itself off from life-interests, has let them

46 Hua. XXV, p. 331, English trans., p. 285.

${ }^{47}$ Hua. VI, p. 338, English trans., p. 291.

48 "Perhaps it will even become manifest that the total phenomenological attitude [Einstellung] and the epoché belonging to it are destined in essence to effect, at first, a complete personal transformation [eine völlige personale Wandlung], comparable in the beginning to a religious conversion [religiösen Umkehrung], which then, however, over and above this, bears within itself the significance of the greatest existential transformation [großten existenziellen Wandlung] which is assigned as a task to humankind as such [die der Menschheit als Menschheit aufgegeben ist]." Hua. VI, p. 140, English trans., p. 137. 
fall." 49 In the attitude of wonder, one becomes aware of the difference between worldrepresentation [Weltvorstellung] and the actual world [wirklicher Welt]. Thus one is driven to search for the world itself, world apart from any pre-given realities. In this position, one is "gripped by the passion for a world-reflection [Weltbetrachtung] and a world-knowledge [Welterkenntnis]."50 One is thus seized by the desire to know the truth of the world itself, to turn and reflect and strive for theoretical knowledge [theoria].

The philosopher who achieves this sense of wonder, at least once in his or her life, becomes receptive to motivations previously unknown. If reason assumes anything less than the infinite, it turns upon itself and consumes itself, it sinks into something reactive rather than productive and creative. With philosophical intuition, a limitless field of work opens on the basis of givenness. It becomes clear that any pre-given thing, precisely to the extent that it is given, is dependent upon some originary givenness: "We see that each theory can only draw its truth itself from originary givenness. Every statement which does no more than confer expression by means of significations precisely conforming to givenness is actually an absolute beginning called upon to serve as a foundation, a principium in the genuine sense of the word."51 Here in $\$ 24$ of Ideas 1, we encounter for the first time the "principle of principles" for phenomenology: "Enough now of absurd theories. No conceivable theory can make us err with respect to the principle of principles, that every originary intuition is a legitimating source of knowledge [Rechtsquelle der Erkenntnis], that everything originarily (so to speak, in its "enfleshed actuality" [leibhaften Wirklichkeit]) offered to us in "intuition" is to be accepted simply as what it is presented as being." 52 It now becomes clear just how radical the revolution is for which Husserl is calling. The "principle of principles" requires the reduction of all pre-givens to "originary intuition," enfleshed intuition. Thus the phenomenological turn implies the radical return to the "intuitive consciousness" of living and embodied subjectivity to whom "originary intuition" is given.

When we speak of "given" or "givenness" [Gegebenheit] we are not referring to the "real" thing out there in the sense of the natural attitude, but to the thing as given within the intentional life. The standard of legitimation for philosophical knowledge is the fullness of intuition in correspondence to givenness within the intentional life. The challenge is to let the phenomenon itself appear in its fullness of intuition. Husserl understands by "phenomenon" not the pre-given objective reality, but the appearing of the thing itself within the immanence of intentional life. "The word 'phenomenon' is ambiguous in virtue of an essential correlation between appearance and that which appears [der wesentlichen Korrelation zwischen Erscheinen und Erscheinendem]. "Phenomenon" in its proper sense means that which appears [Erscheinende], and yet it is by preference used for appearing itself [Erscheinen selbst], for the subjective phe-

49 Hua. VI, p. 332, English trans., p. 285.

50 Hua. VI, p. 331, English trans., p. 285.

${ }^{51}$ Hua. III, p. 52, English trans., p. 44.

52 Hua. III, p. 52, English trans., p. 44 
nomenon (if one may use this expression which is apt to be misunderstood in the vulgar psychological sense)." ${ }^{53}$ Immanence is thus not understood merely as a counterpart to the external world, the "in here" as opposed to "out there," but immanence of the thing itself in its own self-givenness. The "originary intuition" serves as the fundamental criteria for philosophical sources of knowledge, disclosing new regions of givenness, from the discovery of categorial intuition in the Sixth Logical Investigation to the lifeworld [Lebenswelt] in the writings from Husserl's final period. ${ }^{54}$

The naïveté of the natural attitude forecloses the possibility of examining the "root of all things," rizomata panton. The challenge is to disclose a passivity deeper than pregiven constructions and idealizations: "The unreflected in Husserl is neither maintained as such nor suppressed: it remains a weight and a springboard for consciousness. It plays the role of founding and founded; and to reflect is to reveal the unreflected."55 The principle of rationality in the sciences is thus that no pre-given framework or paradigm may foreclose the possibility of givenness to the extent that thing is given in the fullness of intuition. The radicalism of this method is that the realm or domain of givenness opens and expands to include any possible intuition. Thus possibilities stand higher than actualities. Furthermore, meaning or sense is not something merely projected out there by the subject. Indeed I am called first to suspend pre-given attachments, even to myself. Essences are constituted with "originary intuition," as phenomena, or as Husserl says, "mere phenomena" [bloßen Phänomene].56

If the "will to truth" is concerned ultimately, and in a radical way, with the truth-initself, the ideal of completely self-sufficient truth, in and for itself, then we must ask about how truth gives itself, how truth is to appear. It is in this way that Husserl describes phenomenology as a preparatory science: "Above all science must not rest until it has attained its own absolutely clear beginnings." 57 Husserl insists that at present there is no realized rigorous science, that we remain within the realm of shadows, and must continually negotiate between conflicting worldviews: "Each question is controverted, every position-taking is a matter of individual conviction, the interpretation of a school, a point of view [...] I do not say that philosophy is an imperfect science. I say simply that it is not yet a science at all, that as science it has not yet begun [...] Here

53 Edmund Husserl, Die Idee der Phänomenologie. Fünf Vorlesungen. Husserliana II. The Hague: Martinus Nijhoff Publishers, 1950, p. 14. English translation: The Idea of Phenomenology, trans. William P. Alston and George Nakhnikian, Dordrecht: Kluwer Academic Publishers, 1990, p. 11.

54 See Edmund Husserl, Logische Untersuchungen. Zweiter Band. Zweiter Teil. Untersuchungen zur Phänomenologie und Theories der Erkenntnis. Husserliana XIX/2. The Hague: Martinus Nijhoff Publishers, 1984, $\S \S 45-47$. English translation: Logical Investigations. 2. trans., J. N. Findlay, New York: Routledge Publishing, 2001, pp. 280-286.

55 Merleau-Ponty, Nature, p. 72.

56 Edmund Husserl, Einleitung in die Logik und Erkenntnistheorie, Vorlesungen 1906/1907. Husserliana XXIV. Dordrecht: Kluwer Academic Publishers, 1984, p. 209. English translation: Introduction to Logic and Theory of Knowledge, Lectures 1906/07. trans. Claire Ortiz Hill, Dordrecht: Springer Publishers, 2008, p. 204.

${ }^{57}$ Hua. XXV, p. 294, English trans, p. 341 
there is, by and large, no room for private 'opinions,' 'notions,' or 'points of view.' To the extent that there are indeed such in some part of a science, the science in question is not established as such but is in the process of becoming a science and is in general so judged." 58 The task of phenomenology is to unite the ideal of the eidetic sciences with the immanence of givenness in the intentional life. The critical point for Husserl is the suspension of the naive acceptance of the metaphysical hypothesis of the "thing-initself," in order to turn to the immanence of consciousness, in order to examine how the appearances are constituted.

The eidetic insight of phenomenology is to analyze the self-giving of the phenomenon in terms of the essence of the phenomenon in general. This is not the psychological analysis of a presumed interiority of the subject, but analysis of how the phenomenon gives itself in a universal sense. To analyze the phenomenon in terms of its essential constitution is to perceive in the givenness of intentional life the universe of pure ideas. The phenomenological turn critiqued the naive standpoint of the mathematical-natural sciences while maintaining the insight into the need for a universal science of ideas. "As far as intuition extends, so far extends the possibility of a corresponding ideation [...] To the extent that the intuition is pure intuition that involves no transient connotations, but deals with the essence of the appearance of phenomena in general, to the same extent is the intuited essence an adequately intuitive one, an absolutely given essence."59 The strangeness of phenomenology is that absolute givenness does not depend upon us, and yet we are still responsible for it. "The faith that sustains us - in our culture it must not rest here, it can and must be reformed by human reason and human willing - this faith can 'move mountains,' not merely in fantasy, but in reality, only if it is transformed into prudent, rationally insightful ideas, only if in them it brings to complete determination and clarity the essence and possibility of its goal and of the method by which it is attained. In this way, our faith first creates for itself its own rationally justified foundation." 60 It is through the production of ideas by means of insight into the givenness of the things themselves that Husserl believes human culture can attain to a lasting knowledge: "Only such knowledge can become the enduring possession of all men, so that finally, through unlimited acts of cooperation by those who are convinced of this rationality, mountains will be moved, that is, the mere feeling of renewal will turn into the actual process of renewal. "61

With givenness Husserl identifies the deepest and most rigorous philosophical problems, and the only possible response to nihilism. The loss of the sense of "absolute truth" results in the abdication of the "will to truth" and thus in a loss of the sense of the common good. For it is truth as it is desired by persons across their differences that makes good. True virtue emerges only spontaneously in the effort and struggle to surpass oneself for the sake of truth. "For all battles for an autonomy of reason, for the

58 Hua. XXV, pp. 290-291, English trans., pp. 250-251.

59 Hua. XXV, p. 315, English trans., p. 272.

60 Hua. XXVI, p. 5, English trans., p. 327.

${ }^{61}$ Hua. XXVI, p. 5, English trans, p. 327. 
liberation of man from the bonds of tradition, for "natural" religion, for "natural" law, etc., are finally - or reduce to - battles for the universal normative function of the sciences, which have to be justified again and again, and which ultimately encompass the theoretical universe."62 In Ideas II, Husserl refers to nature as that which embraces all things, "consciousness and philosophy," and this nature is identified as "spiritual nature," the nature of spirit.63 The "spirit" is understood here not in terms of some metaphysical entity, but as that which gives itself to itself within a radical immanence, we might even say, givenness itself. Thus givenness encompasses all real and ideal being. The logos of the natural attitude, the logos of the eidetic universe, the logos of the lifeworld, and the logos of the transcendental attitude, are all contained within the universal logos of "spiritual nature." If the logos here refers to different regions of givenness, the task is to examaine how each of the different regions are given within one, universal logos of "spiritual nature."64 The task is to rise to the meaning or sense of givenness in general, in terms of particular instantiations and in terms of absolute givenness itself.

The "crisis" of the European sciences is that philosophy has lost its "target sense." What is needed is "the methodical return to the original source of right, and its cognition, to perfect clarity, insight, evidence."65 If Nietzsche declares the good, the true, and the beautiful, to be "mere words," 66 Husserl struggles to confront the merely subjectiverelative with the things themselves: "In this cognitive method of clarification, what is held to be beautiful and good is normatively confronted with the beautiful and the good itself, which comes into view with complete clarity."67 This process of discernment comes as a result of attaining to perfect evidence according to the givenness of the things themselves: "In complete clarity the essential content of things themselves achieve intuitive actualization and thus at the same time their very value or lack thereof."68 The originary givenness of the true, the good, and the beautiful, happens as a transcendental event, in light of the immanence of the phenomenon. The eidetic analysis reflects on the nature or givenness of the event in order to derive certain essential insights on the basis of and according to the standard of originary givenness. True and genuine knowledge of the beautiful and good, originally generated with imperfect evidence and through rigorous reflection brought into ever-greater fullness of intuition,

62 Hua. VII, p. 207, English trans., p. 292.

63 See Edmund Husserl, Ideen zu einer reinen Phänomenologie und phänomenologischen Philosophie. Zweites Buch: Phänomenologische Untersuchungen zur Konstitution. Husserliana IV. The Hague: Martinus Nijhoff Publishers, 1952. §§48-64. English translation: Ideas Pertaining to a Pure Phenomenology and to a Phenomenological Philosophy. Second Book: Studies in the Phenomenology of Constitution, Dordrecht: Kluwer Academic Publishers, 1989, pp. 181-316.

64 See Jean-Luc Marion, "Husserl et 'le concept large de logique et de logos," in Figures de phénoménologie, Vrin, 2012, pp. 11-26.

65 Hua. VII, p. 206, English trans., p. 288.

66 Nietzsche, Der Wille zur Macht, p. 24: "Jetzt ist alles durch und durch falsch, "Wort," durcheinander, schwach oder überspannt."

${ }^{67}$ Hua. VII, p. 206, English trans., p. 288.

68 Hua. VII, p. 206, English trans., p. 288. 
"alone makes human beings truly virtuous." 69 Thus, the concepts of phenomenology contain within themselves their own normative standards, to the extent that the "principle of principles" holds the research accountable to the givenness of the things themselves. "The idea of truth in the sense of science is set apart from the truth of prescientific life. It wants to be unconditioned truth. This involves an infinity that gives to each factual confirmation and truth the character of being merely relative, being a mere approach in relation precisely to an infinite horizon in which truth-in-itself counts as an infinitely distant point."70

Among the most significant breakthroughs of phenomenology is the insistence that truth be given within the life of the human being. ${ }^{71}$ Each human life is unique to the extent that each life receives itself as a gift. Thus, the human community has a responsibility not only for fostering these gifts, but for bringing the gift of human life into its fullest possibilities and potentials, to bring each gift into the fullness of its essence. The call of renewal is universal to the extent that nothing remains outside or beyond the field of givenness. Each human being, as the one able to ask about the meaning of givenness, is thus responsible for the givenness that is received, and must protect that right and capacity for the others. At the same time, if the "natural law" is to be truly universal, if we claim to speak for the protection of "human rights" and the dignity of the human being, then we must insist that the idea or the essence of the human being is this openness, this incapacity for definition in advance. If the task of phenomenology is in the service of the infinite, and if this infinite is always "on the way," then the human being is made in the image of the infinite, in a constant becoming and development.

In the conclusion to the Vienna Lectures, Husserl presents a final decision, an either-or. Either Europe will fall into a hostility against "its own rational sense of life," into "hostility toward the spirit," and into "barbarism," or Europe will be reborn and renewed "through a heroism of reason."72 At the center of this "crisis" is a decision regarding the status of the human being, the meaning and the ends of the human community, and the rationality of the gift. The task of philosophy is a constant anticipation of the infinite, and a remembrance of what is constantly being passed over in silence. The paradigm shifts which will come as a consequence of the "will to truth," the transformations and revolutions in the orders of knowledge, are not dissimilar from that of Plato's allegory of the cave. To ascend from the shadows to the things themselves will imply the transformation of the way of knowing just as much as it does the meaning and intelligibility of truth. For Husserl, the emphasis is with the receptivity or openness to the truth within one's life. Thus, we must work toward a preparatory science: reason

69 Hua. VII, p. 206, English trans., p. 288.

70 Hua. VI, p. 324, English trans., p. 278.

71 For a recent phenomenological account of "human rights," see James Mensch, "A Theory of Human Rights," February 12, 2010, www.opendemocracy.net. For the development approach to "human rights," see Martha Nussbaum, Creating Capacities: The Human Development Approach, Harvard University Press, 2011.

72 Hua. VI, p. 347, English trans., p. 299 
always "on the way" toward the good, the true, and the beautiful. "Europe's greatest danger is weariness: if we struggle against the greatest of all dangers as 'good Europeans' with the sort of courage that does not fear even an infinite struggle, then out of the destructive blaze of the lack of faith, the smoldering fire of despair over the West's mission to humanity, the ashes of the great weariness, will rise up the phoenix of a new life-inwardness and spiritualization as the pledge of a great and distant future for humankind: for the spirit alone is eternal."73

73 Hua. VI, p. 348, English trans., p. 299. 